\title{
Wątki patriotyczne dotyczące wychowania rodzinnego w prasie górnośląskiej przełomu XIX i XX wieku (na przykładzie wybranych czasopism)
}

\author{
Patriotic Threads Concerning Family Upbringing \\ in the Upper Silesian Press at the Turn of the $19^{\text {th }}$ and $20^{\text {th }}$ \\ Centuries (on the Example of Selected Journals)
}

Słowa klucze: patriotyzm, dawna prasa górnośląska, wychowanie rodzinne, czasopismo „Katolik”, czasopismo „Rodzina”

Key words: patriotism, former Upper Silesian press, family upbringing, "Katolik" magazine, "Rodzina" magazine

Funkcjonowanie rodziny na przełomie XIX i XX wieku na Górnym Śląsku związane było z tzw. wychowaniem domowym. Odzwierciedlenie tego zagadnienia można zaobserwować na łamach prasy górnośląskiej, szczególnie tej związanej z rodziną. Ważny element procesu socjalizacji stanowiło wychowywanie dzieci $w$ duchu katolickim, co było zgodne $z$ ideą wielu czasopism. Sprawy religijne $w$ dawnej prasie dla rodziców czy dzieci przeplatały się z innymi aspektami wychowawczymi. Istotną wartością propagowaną na łamach czasopism było wychowanie patriotyczne. Patriotyzm, rozumiany jako 'miłość ojczyzny, własnego narodu połączona z gotowością ofiar dla nich' (SJPSzym), był ważnym elementem socjalizacji przeniesionej ze sfery szkolnictwa na grunt domowy. Jak stwierdza Ireneusz Karolak: „Obiektem patriotyzmu jest ojczyzna” (KаяоlaK, 1993: 161), mająca różny zasięg terytorialny i wymiar ideologiczny (narodowy/lokalny/regionalny) (КАROLAK, 1993: 162-163).

Patriotyzm nie był jedynie stałą cechą społeczeństwa, ale często sposób jego wyrażania odwzorowywał realia historyczne ${ }^{1}$. Ze względu na ich specyfikę $w$ niektórych okresach postawy patriotyczne mogły się nasilać. W ujęciu językowym były one związane przede wszystkim z komponentem słownikowych definicji pojęcia patriotyzmu odnoszącym się do gotowości ponoszenia ofiar dla ojczyzny. Warto najpierw przedstawić krótki rys historyczny dotyczący omawianego $w$ artykule przedziału czasowego, pozwalający zinterpretować wątki patriotyczne $w$ wymiarze globalnym i lokalnym. Analizowane teksty pochodzą z okre-

* e-mail: wioletta.wilczek@us.edu.pl

1 Według Karolaka „nie jest to pojęcie aksjologicznie jednoznaczne. W całej historii Polski obecna jest dyskusja nad rozumieniem patriotyzmu oraz jego konkretną realizacją w życiu publicznym” (KAROLAK, 1993: 157). 
su niewoli narodowej, sprzed odzyskania niepodległości w 1918 roku. Istotnym punktem dziejowym jest czas I wojny światowej (1914-1918). W bardziej regionalnym kontekście historycznym znaczenie ma fakt, że obszar górnośląski należał do państwa pruskiego, co odzwierciedliło się w sposobie dążenia do polskości wśród mieszkańców regionu. Górny Śląsk $w$ wysokim stopniu sprzeciwiał się germanizacji i polityce tzw. kulturkampfu². Jednym ze sposobów protestu Górnoślązaków były liczne organizacje i stowarzyszenia, manifestujące narodowe aspiracje na forum publicznym, niejednokrotnie prześladowane przez władze pruskie (zob. PATER, 1998). Ważny element tej walki stanowiła prasa, a celem, jaki za jej pośrednictwem starano się osiągnąć, było kształtowanie świadomości narodowej obywateli. Badacze zauważają udział czasopiśmiennictwa $w$ tym procesie $w$ omawianym przeze mnie zakresie czasowym:

Mimo że po 1889 roku program czasopism górnośląskich nadal koncentrował się przede wszystkim na sprawach związanych z obroną języka ojczystego, to akcentował coraz wyraźniej aktywne propagowanie i umacnianie polskiej świadomości narodowej, podkreślając polski charakter Górnoślązaków, ich historyczny, kulturalny, szczepowy i językowy związek z resztą narodu polskiego. Nawet na łamach „Katolika” zaczęła pojawiać się po roku 1889 tematyka narodowa, jakkolwiek nadal posługiwano się sankcją religijną dla uświęcenia idei narodowości.

GLENSK, 1999: 24-25

Najbardziej znaną postacią górnośląskiej walki o odrodzenie narodowe był Karol Miarka:

Z chwilą kiedy w 1869 roku zaczął wydawać pismo „Katolik” (od 1870 zyskało rangę tygodnika, Miarka kierował nim do 1881 roku) polskość na Górnym Śląsku otrzymała swój stały periodyk, wokół którego ogniskował się narodowy ruch polski. Specjalną rolę odegrało to pismo w dobie Kulturkampfu, kiedy skupiła się wokół niego cała ludność katolicka na Śląsku (w tym wielu katolików pochodzenia niemieckiego).

TROJNAR, 1992: 31

Założenia ideologiczne czasopism pozostały bez zmian, dlatego też wątek odrodzenia narodowego i propagowanie polskości ${ }^{3}$ były $w$ analizowanym okresie kontynuowane $w$ prasie regionalnej.

2 Jak pisze Eleonora Sapia-Drewniak: „Poczynając od zainicjowanego w 1871 roku przez Bismarcka tzw. kulturkampfu, pozbawiono ludność polskojęzyczną możliwości uczenia się w szkole w swoim języku macierzystym. [...] Kulturkampf godził nie tylko w język polski, ale i w Kościół katolicki będący oparciem dla kultury duchowej społeczności śląskiej. [...] Traktowanie ludności polskojęzycznej jako obywateli gorszej kategorii pogłębiało naturalny w takich wypadkach opór" (SAPIA-DreWNIAK, 2016: 50).

${ }^{3}$ Zgodnie z twierdzeniem Karolaka: „Innym składnikiem, wyróżnianym, a niekiedy utożsamianym z ojczyzną, jest państwo. W tym przypadku patriotyzm odnosi się do walki o to państwo, suwerenność (dążenia niepodległościowe i separatystyczne, walka o autonomię), bądź do ochrony tego państwa, jego interesów, racji stanu, rządu, instytucji, ładu społecznego etc." (KARolaK, 1993: 165). 
Celem mojej analizy jest wyekscerpowanie z wybranych czasopism elementów wychowania w duchu patriotycznym i narodowym ${ }^{4}, \mathrm{z}$ racji czego artykuł można uznać za poglądowy i sygnalizujący możliwe obszary dalszych badań. Źródło materiałowe stanowi czasopismo „Rodzina” (R)5 będące dodatkiem do „Katolika” (K). W związku z funkcjonowaniem „Rodziny” jako integralnej części wskazanego czasopisma traktuję założenia i cele przyświecające twórcom obu tytułów jako tożsame. Dopełnieniem przykładów będą pojedyncze wyimki z artykułów zamieszczanych w „Katoliku” (ze względu na zróżnicowaną zawartość czasopisma i istnienie tematycznych dodatków treści dotyczące spraw wychowawczych są $w$ nim zmarginalizowane na rzecz spraw politycznych, gospodarczych czy aktualności z regionu, kraju i świata). Materiał analityczny obejmuje wydania gazety z dwudziestu ośmiu lat - od 1890 do 1918 roku$^{7}$. Przedmiotem mojego zainteresowania są przede wszystkim językowe i ideologiczne wykładniki patriotyzmu jako elementu językowego obrazu świata stanowiącego swoistą interpretację rzeczywistości (zob. BARTMıńsKı, 1999). Istotną kategorią będzie również wartościowanie (por. PuzrninA, 1992) ukazujące pozytywne lub negatywne wartości dotyczące komponentów patriotyzmu.

Charakter omawianej prasy wskazuje na rodziców jako jej założonego odbiorcę, należy jednak podkreślić fakt, że także w przypadku czasopism adresowanych do dzieci (np. „Anioł Stróż”, „Dzwonek”) idea patriotyzmu i poczucia tożsamości narodowej jest obecna. Irena Socha zauważa występujące $w$ prasie przełomu wieków wpajanie dzieciom dążenia do działań na rzecz odrodzenia się Polski:

Czasopisma dla dzieci zaczęły powstawać na Górnym Śląsku w latach osiemdziesiątych i dziewięćdziesiątych XIX wieku, największe nasilenie przypadło jednak na początek wieku XX. Można dostrzec zbieżność z ogólną dynamiką rozwojową prasy śląskiej oraz wpływ ówczesnej sytuacji politycznej, gdy obok partii Centrum pojawiają się nowe siły - narodowa demokracja i socjaldemokracja - formułując nowe programy wychowania narodowego młodego pokolenia.

SochA, 1999: 43

Kształtowanie postaw patriotycznych było kwestią ewolucji światopoglądowej, na której zaważyły przede wszystkim wydarzenia historyczne i aktywny sprzeciw wobec procesu germanizacji: „W rozwoju większości śląskich czasopism dla dzieci w języku polskim występuje, między innymi, prawidłowość, którą można by określić formułą »od uniwersalizmu do patriotyzmu «" (SochA, 1999: 43). Propagowanie wartości uniwersalnych, istotnych $w$ procesie socjalizacji, zostaje wzbogacone o krzewienie wartości patriotycznych,

${ }^{4}$ Jak stwierdza Mirosław Wójcik: „Specjalne zasługi ma Karol Miarka w budzeniu świadomości narodowej Polaków w zaborze pruskim, szczególny ma też udział $w$ tworzeniu narodowo-chrześcijańskiego modelu wychowania w rodzinie" (Wóıcıк, 1991: 64).

5 „Rodzina” to kilkustronicowy dodatek do „Katolika” i innych górnośląskich czasopism, poświęcony „wychowaniu i nauce domowej”.

${ }^{6}$ Periodyk wydawany w latach 1868-1931.

7 Po 1916 roku nastąpiła przerwa w wydawaniu „Rodziny”, więc w tym wypadku zakres analizy jest o dwa lata krótszy. 
stanowiących odpowiedź na realne potrzeby społeczne oraz aktualną sytuację narodowo-polityczną.

Metody wychowawcze $w$ rodzinie na łamach pism z kręgu „Katolika” skupione były wokół działań przykładem własnym, perswazji i transponowania kultury chrześcijańsko-narodowej (WóıcıK, 1994: 304). Wszystkie trzy sposoby edukacji można zaobserwować $w$ analizowanej prasie. Są one odzwierciedlone $w$ artykułach, wierszykach, poradach (także we fragmentach powieści, przedrukach opowiadań, które, z uwagi na swój charakter i odrębność formalną od specyfiki czasopism, nie stanowią przedmiotu mojego oglądu badawczego). Ze względu na germanizację systemu szkolnictwa ośrodkiem krzewienia polskości był dom.

Kształtowanie ducha patriotyzmu odbywało się $w$ procesie wychowawczym na kilku głównych poziomach ${ }^{8}$ :

1. szacunek do języka ojczystego,

2. miłość do ojczyzny,

3. kultywowanie tradycji i pamięć o historii,

4. docenianie aktów bohaterstwa i odwagi,

5. poświęcenie i oddanie dla rodzimego kraju,

6. wpajanie systemu wartości moralnych i duchowych (np. rodzina, ojczyzna).

Przytoczony podział będzie stanowić punkt wyjścia prezentacji materiałowej. Wykorzystane przykłady są reprezentatywne dla omawianych elementów, a ich liczba została ograniczona ze względu na wielowątkowość niniejszego artykułu.

\section{Szacunek do języka ojczystego}

Rozpoczynając od poszanowania języka polskiego, można przedstawić wniosek badawczy dotyczący tego zagadnienia w dawnej prasie górnośląskiej:

Wiele artykułów poświęcono problemowi nauczania, a także uczenia się mowy ojczystej. Zyskiwała ona nie tylko znaczenie kodu językowego. Język polski postrzegano jako zwerbalizowanie myśli i uczuć Polaków, czego nie da się wyrazić $w$ żadnym innym języku, także niemieckim, bo ten nie zapada głęboko w świadomość polską.

WóscıK, 1994: 307

Pierwszym wyrazistym wykładnikiem $w$ tym zakresie są podtytuły wskazanych czasopism: Szanuj mowę ojców! to prawo Boga a człowieka obowiązek. (K, 1890, nr 63: 1); Uczcie dzieci czytać po polsku! (R, 1900, nr 4: 1). Zastosowane czasowniki w formie imperatywnej (szanuj, uczcie) pełnią funkcję perswazyjną, nakłaniając czytelników do dbałości o polską mowę. Również na poziomie zawartości czasopism kwestia pielęgnowania języka ojczystego jako sprzeciw wobec germanizacji jest niejednokrotnie podkreślana:

${ }^{8}$ Wydzielenie poszczególnych kategorii jest autorską koncepcją, podyktowaną obserwacjami analizowanego materiału. Większość zagadnień występuje $w$ kontekście wychowania patriotycznego poza omawianą prasą śląską. 
Smutną jest rzeczą, że dzisiejszy system szkólny ojczystego języka nie uwzględnia i trzeba nad tem bardzo ubolewać. Ale ponieważ nie w mocy naszej, system ten zmienić, trzeba o tem pamiętać, aby dzieci polskich rodziców nie poniosły szkody co do języka ojczystego. To obowiązek rodziców, ojców, matek, krewnych i opiekunów. [...] Bo to obowiązek rodziców, aby dbali o pielęgnowanie darów Bożych; do tych darów należy także język ojczysty. [...] muszą jednem słowem, mówić po polsku, a nie tylko mówić tak sobie, gdzieś w kącie, jeno mówić śmiało wszędzie, gdzie można, gdzie okazya jest po temu, bo przez to okazują, że mają miłość do swej ojczystej mowy, a razem też miłość do swojego ludu9

K, 1890, nr 49: 1

Gdy dziatwie naszej uniemożliwiono w szkołach nauczenie się czytania i pisania polskiego, pozostał jej jedyny polski Elementarz. Wskutek nieznajomości czytania i pisania polskiego uczęszcza wiele dzieci polskich na obcą naukę katechizmową ze szkodą dla ich duszy.

K, 1910, nr 83: 3

Język ojczysty jawi się jako synonim daru Bożego, przedmiotu czci i pielęgnacji, wyzyskującego religijne aspekty dbałości o mowę przodków (obca nauka katechizmowa utożsamiana jest ze szkodą). Istotna okazuje się także kategoria obowiązku, w której rozpatrywana jest konieczność używania języka ojczystego. Należy również podkreślić pojawiającą się świadomość dotyczącą bezskuteczności dążenia do zmian politycznych czy społecznych, sprzeciwiających się procesom germanizacyjnym (nie $w$ mocy naszej system ten zmienić; forma bezosobowa czasownika: uniemożliwiono).

$Z$ racji adresowania artykułów $w$ wymienionych periodykach do matek czy obojga rodziców, właśnie do nich $w$ formie apelatywnej kierowane są niektóre treści:

Użyjmy darów naszych na podniesienie chwały lubej Polski! Kiedy jej Niebo odmawia politycznego znaczenia, przyłóżmy się, aby ta ukochana kraina, doszła do moralnej wysokości! Przejmijmy się naprzód na wzór innych niewiast, miłością narodowego języka; sam z siebie piękny, brzmi wdzięczniej w ustach naszych, i mocniej serce dotyka; nie mniej jest miły Niebu w gorących modłach, rozumieją go cienie prababek $w$ krainie błogosławionych. Porzućmy obcy, a często szkodliwy dla naszej moralności, dla ducha narodowego, dla ojczystej literatury języka.

$\mathrm{R}, 1910$, $\mathrm{nr}$ 4: 4

Na pierwszym miejscu powinniśmy kochać język swój polski. Piękny, i bardzo piękny nasz język. [...] Szanujmy ten język i my, i nie pozwalajmy dzieciom naszym mówić obcymi językami. Uważajmy to za zdradę, za zdeptanie honoru ojców naszych, gdy dzieci pomiatają własnym ojczystym językiem, i gdy najchętniej szwargocą jakimbądź innym obcym językiem.

R, 1912, nr 18: 2

${ }^{9}$ Wszystkie cytowane fragmenty z dawnej prasy zostały przytoczone z zachowaniem oryginalnej pisowni. Pogrubienia w cytatach pochodzą od autorki artykułu. 
Duchem katolickiego wymiaru czasopism jest korelacja sfery religijnej z niewolą narodową Polski (Niebo odmawia politycznego znaczenia). Warto również zwrócić uwagę na My inkluzywne, wyrażone w formach czasownikowych: przyłóżmy się, przejmijmy się, porzućmy, szanujmy, nie pozwalajmy. Czasowniki mobilizujące do działania i aktywności zachęcały, wręcz nakłaniały, do walki o język ojczysty, a najskuteczniejszym jej przejawem była rezygnacja z obcych wpływów językowych. W prasie zwracano także uwagę na negatywne skutki uczenia się i używania języków obcych. Sam taki proces uznawany był za zdradę czy zdeptanie honoru. Element pejoratywnego wartościowania języków innych niż polski stanowiło określanie posługiwania się nimi czasownikiem szwargotać, definiowanym jako 'mówić w języku, którego ktoś nie zna lub nie lubi, zwłaszcza po niemiecku' (SJPSzym). W kontekście historycznym dotyczącym germanizacji odnosił się on przede wszystkim do języka niemieckiego. Używanie języka było także (np. na łamach „Katolika”) powiązane z religią:

[...] póty wiary katolickiej na polskim Górnośląsku, póki lud swój język ojczysty zatrzyma. To też „Katolik” pomny na te słowa, ostrzegając lud polsko-katolicki przed wstępowaniem do niemieckich „vereinów” broni go równocześnie przed sosyalizmem.

K, 1918, nr 148: 3

W dawnej prasie dotyczącej rodziny w znacznym stopniu nakładano odpowiedzialność na rodziców w zakresie nauki języka polskiego, na przykład:

Każdy ojciec i każda matka powinna to mieć na sumieniu, że dziecko ostawione bez umiejętności czytania polskiego, pisania, zawsze będzie sierotką-kaleką niezdatną do podjęcia walki życiowej. Będzie to istota rzucona na srogą pastwę poniewierki i germanizacyi.

R, 1913, nr 7: 4

Matki opuszczają się na nauczycieli i księdza, a same wyrzekają się szczytnego powołania wychowywania dzieci. Dla tego też mnożą się u nas zbrodniarze, bo dzieci nie wychowane religijnie $w$ języku ojczystym, nie wiedzą co złe a co dobre i grzęzną $w$ błocie niemoralności.

K, 1918, nr 49: 7

Najlepszym środkiem zaradczym przeciwko tej nowomodnej truciznie rozsiewanej przez obecny system nauki - jest książeczka ojca Bogumiła, którą szanownym naszym Czytelnikom jak najgoręcej polecamy, boć przecież ich radością i zaszczytem są grzeczne i dobrze wychowane dzieci.

K, 1890, nr 48: 3

Odwołanie do sumienia i użycie leksemów z rezerwuaru wyrazów nacechowanych (sierotka, kaleka, poniewierka, srogi, zbrodniarze, niemoralność, trucizna) ma wzmóc poczucie winy odbiorców i za pomocą wypowiedzi perswazyjnych nakłonić ich do działania. Perswazja jest nieodłącznym elementem między innymi socjalizacji jednostki, dyskursu pedagogicznego, przyswajania kultury własnego narodu (HABRAJSKA, 2005: 109). 


\section{Miłość do ojczyzny}

Wykładnikiem wychowania patriotycznego było zaszczepianie $w$ dzieciach miłości do ojczyzny. Umiłowanie rodzinnego kraju, którego wyznacznikiem staje się na przykład praca, stanowi nieodłączny czynnik rozwoju narodu i budowania jego przyszłości. Istotnym wyróżnikiem jest pojęcie tzw. patriotyzmu prawdziwego:

Patryotyzm prawdziwy polega na miłości ojczyzny i nie ma nic wspólnego z nienawiścią do wroga.

K, 1918, nr 97: 5

W ten sposób łagodzony jest wydźwięk kategorii „swój-obcy”10 - obcy potraktowany zostaje w ujęciu ideologicznym jako inny, a nie jako wróg. Zdaniem Bożeny Witosz: „Inny konotuje istnienie różnicy, ale nie niesie ona negatywnych treści związanych z pojęciem obcości: dystansu, zamknięcia, poczucia zagrożenia" (Wıtosz, 2010: 19). Duch patriotyczny wyrażany jest poprzez cechy pozytywne, na przykład szacunek:

Szanujmy siebie, a i nas uszanuje każdy, choćby i obcy i nasz wróg.

R, 1912, nr 18: 2

W kontekście miłości do ojczyzny należy wspomnieć jeszcze o powszechnej $w$ analizowanej prasie metaforze ojczyzna jako rodzina ${ }^{11}$. Takie metaforyczne porównanie ${ }^{12}$ świadczy o silnych więziach z ziemią ojczystą i unaocznia wysoką rangę ojczyzny w życiu jednostki:

[...] Ojczyzna jest to rodzina we wielkiej postaci; jest częścią świata, do której Bóg przywiązał nasze ciało i naszą duszę. Ojczyźnie winniśmy wszystko, czem jesteśmy. Jest to sprawa serca i poczciwości. Każdy członek tej wielkiej rodziny tj. ojczyzny, który jej nie przynosi swojej części usług i dobra, uchybia swym obowiązkom i jest złym członkiem tej rodziny; kimkolwiek on jest, jeżeli nie wzbogaca wszelkich uczciwych potrzeb i usiłowań społeczeństwa, wszelkiemi swemi siłami, wszelkiemi swemi dobremi zamiarami, krzywdzi ojczyznę i jest [jej - W.W.] nieuczciwym członkiem [...].

R, 1914, nr 5: 2

W przytoczonym fragmencie oddanie ojczyźnie traktowane jest jako obowiązek. Poczucie patriotyzmu i powinności wobec ojczystego kraju łączy się wielokrotnie z pojęciem narodowości / poczucia narodowego:

10 Tworzenie takiej opozycji jest charakterystyczne dla pojęcia patriotyzmu: „Wydaje się, że charakter zbiorowości ludzi tworzących aktywnie substancję ojczyzny jest jednym z najważniejszych czynników determinujących kształt patriotyzmu. Większa lub mniejsza, zbiorowość taka integruje jednych ludzi i jednocześnie wyklucza pozostałych, różnicując ich według dychotomii swój-obcy" (KAROLAK, 1993: 164).

${ }_{11}$ Metafora ta funkcjonuje także w odwrotnej konfiguracji: rodzina jako ojczyzna.

12 Inne przykłady i konteksty użycia - zob. WıLCZEK, 2018. 
[...] czemuż kobieta nie ma zaczerpnąć tej ożywczej wody, czemu nie ma się ogrzać $w$ dobroczynnem świetle słońca oświaty, aby się stała wyższą umysłem, sercem szlachetniejszą, lepszą $w$ postępowaniu, milszą w obejściu, ofiarną dla wyższych celów, jakiemi są: religia i narodowość!

R, 1910, $\mathrm{nr} 22: 4$

Oby $w$ narodzie naszym jaknajwięcej było rodzin licznych, przejętych duchem chrześciańskim i poczuciem narodowem.

R, 1904, nr 10: 4

Odczytuj sobie te rady codziennie, a przynajmniej w Niedzielę, w czasie Mszy św.; mogą Ci pomódź do zdobycia za łaską Boską najwyższego rozumu to jest cnoty, a zatem do lepszego pełnienia obowiązków względem rodziny i Ojczyzny.

$\mathrm{R}, 1894, \mathrm{nr} 3: 8$

Miłość do kraju ojczystego jest skorelowana z traktowaniem go jako najlepszego miejsca do egzystencji człowieka. Przebywanie poza granicami rodzimego kraju generuje uczucie tęsknoty i pustki, a powrót do niego wyzwala emocje związane ze wzruszeniem i wspomnieniami z lat dziecięcych. Pozytywne nastawienie i przywiązanie do ojczyzny wyrażają przykłady:

Płyńcie, słodkie łzy; bo nigdy

Tak nie wita świat,

Jak witają, gdy wracamy

Do rodzinnych chat.

$\mathrm{R}, 1903, \mathrm{nr} 12: 1$

Ziemia rodzinna! Słowa te obejmują świat cały, budzą w sercach tysiące wspomnień jasnej młodości, raju dziecięstwa, który zniknął na zawsze. Któżby mógł zapomnieć dom rodzinny, tę bezpieczną przystań, z której bez troski spoglądał w życie, zdające się zapowiadać tyle dobrego i pięknego!

R, 1912, nr 22: 3

Kto nie ma skiby ziemi z pracy lub spuścizny,

Ten zawsze jest wygnańcem, pasierbem ojczyzny.

R, 1894, nr 7: 8

Po Bogu i rodzicach niech ten zagon ziemi stanie się dla nich największą świętością, którejby nie odstąpiły nikomu za żadne skarby świata!

R, 1912, nr 22: 4

Ojczyzna (zmetaforyzowana także jako dom rodzinny) jest w nich przedmiotem pozytywnego wartościowania (bezpieczna przystań, największa świętość, raj dziecięstwa).

\section{Kultywowanie tradycji i pamięć o historii}

Stefania Walasek, badająca edukację patriotyczną w życiu rodzinnym na podstawie wspomnień różnych osób, wskazuje, że „w polskich rodzinach wychowanie patriotyczne 
ściśle było związane z poznaniem historii ojczystej" (WALASEK, 1996: 136). Podobne stanowisko zajmują twórcy omawianej prasy, akcentując niejednokrotnie potrzebę znajomości historii własnego narodu, by lepiej budować jego przyszłość. W prasie unaoczniane są także niewola narodowa oraz trudna sytuacja Polaków zamieszkujących region i ojczyznę:

Żyć nam tak ciężko na własnej ziemi,

$Z$ rozpaczą woła młody i stary,

Nie pomni na to, że Bóg nad niemi,

I nigdy tracić nie trzeba wiary.

Za ojców grzechy i własne winy,

Bolesne wprawdzie znosimy kary,

Lecz Bóg, z którego woli cierpimy,

O nas pamięta. Nie traćmy wiary!

R, 1912, nr 23: 3

Chociaż pozbawieni jesteśmy własnego państwa i własnych rządów, i chociaż na różnych ziemiach polskich na każdym niemal kroku życie nasze jest krępowane, to jednak mamy pewne spuścizny przeszłości, które powinniśmy szanować, jako nasze narodowe świętości. Te spuścizny [...] stanowią naszą odrębną narodową cechę i stwierdzają, że istniejemy jako Polacy.

R, 1912, nr 18: 2

Brak istnienia własnego państwa i niewolę narodową, przejawiającą się w wielu aktach ubezwłasnowolnienia, Polacy wiązali z ingerencją boską ${ }^{13}$, którą należy znosić z cierpliwością (Nie traćmy wiary!). Ówczesna sytuacja była synonimem kary, poniesionej za grzechy przodków i własne, wina nie jest zatem po stronie zaborcy i czynników zewnętrznych. Mimo trudnych, niesprzyjających okoliczności społecznych autorzy artykułów w czasopismach nawołują do poszanowania własnej historii i narodowości.

Aktem patriotyzmu są także przejawy podtrzymywania tradycji, na przykład śpiew ojczysty/narodowy:

Niemasz nic wspanialszego, piękniejszego i bardziej przemawiającego do duszy, jak śpiew. Zwłaszcza śpiew ojczysty ceni każdy naród, rozwija go, podnosi, uszlachetnia i szczyci się nim przy każdej sposobności. [...] Bez pieśni nie masz narodu - nie masz przyszłości. [...] Pieśń polska sławną jest od wieków. [...] Dlatego Polacy powinni przechowywać ten drogi skarb, pielęgnować i rozwijać. [...] Toteż krzewmy śpiew nasz narodowy. Nie zapominajmy o ślicznych polskich piosenkach i pieśniach; uczmy tych śpiewek dziatwę naszą, niech i nadal przechodzą z ojca na syna i służą ku rozrywce i przyjemności naszej.

R, 1911, nr 13: 3

13 Można to powiązać z religijnym wymiarem czasopisma: „[...] »Katolik« przez wiele lat uświadamiał swoich czytelników powtarzającymi się ciągle w winiecie tytułowej hasłami, iż działanie prasy jest działaniem popieranym przez Boga, Kościół i religię" (RATAJEWSKI, 1999: 54). 
Pieśni polskie to pierwsze i najprostsze lekcye miłości ojczyzny, miłości wszystkiego, co swojskie, co nasze.

R, 1912, nr 18: 4

Ten element wychowania wskazuje na wspólnotę i ciągłość tradycji mieszkańców ziem polskich, jest nawet warunkiem koniecznym do istnienia narodu. Kultywowanie pieśni narodowych (przechowywać skarb, pielęgnować, rozwijać) wielokrotnie pojawia się w omawianej prasie, można je zatem uznać za istotny czynnik budowania tożsamości narodowej Polaków.

\section{Docenianie aktów bohaterstwa i odwagi}

Kolejnym elementem socjalizacji patriotycznej jest pozytywna waloryzacja czynów będących przejawami bohaterstwa i odwagi (często traktowanymi jako ofiara i obowiązek), przedmiotem zasług i szacunku:

Zresztą, i duch zgody rodzi często czyny bohaterstwa. Kto w drobnych rzeczach umie zgodnie ustąpić, kto potrafi poświęcić dla zgody osobiste swe zadowolenie, ten zazwyczaj staje się nieugiętym bohaterem, gdy sumienie nie pozwala mu odstąpić od obowiązku.

R, 1910, nr 4: 3

Posłuszeństwo głosowi obowiązku, choćby największą okupione ofiarą, jest treścią istnienia, szczytem obywatelskości. I dziś jak dawniej winniśmy pracować, żyć nadzieją i umierać za świętą sprawę.

R, 1913, nr 21: 3

W cztery lata znowu później 1848 roku przychodzi on na Górny Ślązk do Opola, gdzie przez blisko 10 lat pracuje jako radzca szkolny i główny inspektor szkół ludowych, niezmierne zasługi pokładając około wychowania dziatwy szkolnej w języku ojczystym.

K, 1917, nr 128: 6

Składnikiem patriotyzmu było także propagowanie przejawów bohaterstwa, czego dowodem może być artykuł Kilka przykładów dzielności dawnych Polaków (R, 1895, nr 6: 6) lub fragment:

Z dniem 6-go maja br. upływa z górą lat 40, jak jeden z najzasłużeńszych wobec ludu polskiego mężów rozpoczął swój zawód literacki. [...] Józef Chociszewski zna Śląsk, kocha go i pracuje dla niego. [...] Józef Chociszewski należy do nauczycieli naszego ludu, on uczył czytać, pisać, kochać Boga, Kościół święty, ziemię ojczystą i narodowość polską.

K, 1900, nr 40: 3

W dawnej prasie często występują wyrażenia odnoszące się do omawianego kręgu znaczeniowego, na przykład bohaterski czyn, piękny wzór, pełen nieustraszonego męzstwa. 


\section{Poświęcenie i oddanie dla rodzimego kraju}

Istotnym elementem językowego obrazu patriotyzmu było poświęcenie dla ojczyzny. Pole semantyczne tego wyrażenia bezsprzecznie wiąże się z leksemem ofiara (ponieść ofiarę, złożyć $w$ ofierze). Taka semantyka wyzwala religijne konotacje:

Wszak Polkom miłość kraju jest wrodzona, wszak dla jego obrony, nieraz matka wysyłała syna, żona uzbrajała męża, siostra brata; żadna ofiara nie była wielką, kiedy szło o sławę rodzinnej ziemi. [...] O niewiasty polskie! Dajcie ten dowód miłości rodzinnej swej ziemi.

R, 1910, $\mathrm{nr} 4: 4$

Miłość do rodzinnej ziemi zawsze głęboko tkwiła w sercu Polaków, którzy ostatnią kroplę krwi oddawali $\boldsymbol{w}$ jej obronie. I dzisiaj $w$ ludzie polskim nie wygasło to szczere przywiązanie do miedzy rodzinnej, której niestety ubywa coraz więcej.

Poniesienie ofiary jawi się jako dowód miłości. Oddanie ojczyźnie niejednokrotnie jest skorelowane ze wspomnianą już kategorią powinności, obowiązku.

\section{Wpajanie systemu wartości moralnych i duchowych}

Oznaki patriotyzmu w wychowaniu dzieci objawiały się nie tylko w powinnościach wobec ojczyzny, ale również poprzez wpajanie dzieciom istotnych cech tworzących wachlarz pozytywnych wartości ${ }^{14}$, które niejednokrotnie zaznaczały się już we wcześniejszych przykładach. Wśród nich można przede wszystkim wskazać leksemy praca/pracowitość, ambicja, posłuszeństwo:

Naród zamiłowany w gorliwej pracy i pilności we wszystkich stanach i zawodach społecznych, ma wielką, niczem nie pokonaną siłę żywotności. Taki naród potęínieje w siły materyalne (zamożność), moralne (cnoty) i fizyczne (moc osobistą), taki naród nigdy nie ginie.

R, 1914, nr 5: 3

Zdarza się nawet, że rodzice nierozważnie niszczą w duszy dziecka szlachetne zasady ambicyi, tłumią $w$ samym początku ów cenny przymiot, wiodący młodzież do postępu, do ideałów.

R, 1910, nr 24: 4

Posłuszeństwo rodzicom, zwierzchnikowi, krajowi powinno być kamieniem węgielnym wychowania. Wiek dziecinny zacząć powinien od posłuszeństwa. Dojrzałość nas od niego nie uwalnia, posłuszeństwo krępuje nas aż do końca.

${ }^{14}$ Wpajanie dzieciom systemu wartości i zachowań powiązane było także ze sposobem funkcjonowania rodziców. Wiele artykułów w omawianych periodykach poświęcono „kreowaniu wzorców osobowych matki i ojca" (Wóscık, 1994: 305). 


\section{[...] Przedewszystkiem bądźcie przejęci poczuciem obowiązku względem Boga,} potem względem rodziny, współbraci, względem podwładnych i sług, a wreszcie wzgldem (sic!) ojczyzny, która z swej strony ma względem was zobowiązania.

Właściwy sposób postępowania i zachowań jest niewątpliwie powiązany z oddaniem ojczyźnie i dążeniem do odzyskania własnej narodowości. Rozwój społeczeństwa, określony mianem dążenia do postępu, do ideałów, stanowi nieodzowny warunek jego funkcjonowania i przetrwania.

Reasumując, można stwierdzić, że językowe i ideologiczne elementy patriotyzmu $w$ aspekcie wychowania są obecne $w$ dawnej prasie górnośląskiej. Zróżnicowanie czasowe materiału analitycznego przekonuje o trwałych komponentach wątków patriotycznych $w$ dawnej prasie. Należy jednak podkreślić, iż sam leksem patriotyzm nie występuje zbyt często, duch patriotyczny skondensowany jest w pojęciach ojczyzna i narodowość. Socjalizacja dzieci w tym zakresie odbywa się na kilka różnych sposobów. W artykułach adresowanych głównie do rodziców podnoszone są kwestie: dbałości o ojczystą mowę, miłości do ojczyzny, pamięci o historii własnego narodu, doceniania bohaterskich czynów, ponoszenia ofiary dla ojczyzny oraz wpajania systemu wartości. Wskazane zakresy tematyczne tworzące językowy obraz patriotyzmu w wielu przypadkach traktowane są w kategoriach powinności i obowiązku, co w płaszczyźnie językowej wyrażane jest za pomocą zwrotów apelatywnych. Dążenie do odzyskania narodowej wolności i ujawnianie stosunku do ojczyzny, chociaż $w$ ogólnym wymiarze będące sprzeciwem wobec germanizacji, w przeważającym stopniu jest realizowane w kategorii „za”, a nie „przeciw” (w tym wypadku największe znaczenie ma nauka języka polskiego i sprzeciw wobec obcych wpływów). Aprobująca postawa odnosi się do własnej ojczyzny, kultury narodowej, tradycji i innych wartości. Zarysowany $w$ artykule obszar tematyczny przekonuje o wysokiej randze wychowania patriotycznego w edukacji domowej na Górnym Śląsku na przełomie XIX i XX wieku.

\section{Źródła}

K - „Katolik. Pismo poświęcone ludowi ku cnocie, nauce, zbogaceniu” (1890-1918).

R - „Rodzina. Pismo poświęcone wychowaniu i nauce domowej” (1890-191615).

\section{Słowniki}

SJPSzym - Szymсzак M., red., 1995: Słownik języka polskiego PWN. T. 1-3. Warszawa.

\section{Literatura}

BARTMIŃSKı J., 1999: Punkt widzenia, perspektywa, językowy obraz świata. W: BARTMIŃSKI J., red.: Językowy obraz świata. Lublin, s. 103-120.

\footnotetext{
15 Po 1916 roku nastąpiła przerwa w wydawaniu „Rodziny”.
} 
GLENSK J., 1999: Znaczenie prasy polskiej w budzeniu świadomości narodowej na Górnym Śląsku (1869-1914). W: GotєBıowska J., KagAniec M., red.: Regionalna prasa polska na Górnym Ślq̨sku $w$ latach 1845-1996. Materiały sesyjne. Katowice, s. 21-29.

HAвRAJSKa G., 2005: Nakłanianie, perswazja, manipulacja językowa. „Acta Universitatis Lodziensis. Folia Litteraria Polonica" VII, nr 2, s. 91-126.

Karolak I., 1993: Patriotyzm. W: Bartmiński J., Mazurkiewicz-Brzozowska M., red.: Nazwy wartości. Studia leksykalno-semantyczne. Lublin, s. 157-176.

Pater M., 1998: Polskie dążenia narodowe na Górnym Śląsku (1891-1914). Wrocław.

Puzrnina J., 1992: Język wartości. Warszawa.

RatajeWski J., 1999: Prasa polska na Śląsku w XIX i na poczq̨tku XX wieku o sobie. W: GotęBıwSKA J., KAgAniec M., red.: Regionalna prasa polska na Górnym Śląsku w latach 1845-1996. Materiały sesyjne. Katowice, s. 52-65.

Sapia-Drewniak E., 2016: Działalność oświatowa polskich towarzystw na Górnym Śląsku na przełomie XIX i XX stulecia. „Studia Paedagogica Ignatiana. Rocznik Wydziału Pedagogicznego Akademii »Ignatianum« $w$ Krakowie" XIX, nr 2, s. 47-63.

Socha I., 1999: Polskie czasopisma dla dzieci i młodzieży na Śląsku pruskim. W: GotŁ̨вıwska J., KaganieC M., red.: Regionalna prasa polska na Górnym Śląsku w latach 1845-1996. Materiały sesyjne. Katowice, s. 42-51.

Trojnar A., 1992: Kulturkampf a rozwój polskiej świadomości narodowej na Górnym Śląsku. W: PAWŁowıczowa M., red.: Książka polska na Śląsku $w$ drugiej połowie XIX wieku. Zarys problematyki. Katowice, s. 24-35.

WALASEK S., 1996: Kształtowanie postaw patriotycznych $w$ polskich rodzinach na przełomie XIX i XX wieku. Wstępne wyniki badań. „Zeszyty Naukowe Wyższej Szkoły Pedagogicznej w Bydgoszczy. Studia Pedagogiczne", z. 28, s. 131-139.

WıLCzeK W., 2018: Leksyka zwiq̨zana z rodziną $w$ dawnej prasie górnośląskiej. W: MAczYŃsKı M., Horyń E., Zmuda E., red.: W kręgu dawnej polszczyzny. T. 6. Kraków, s. 111-124.

Wıтosz B., 2010: O dyskursie wykluczenia i dyskursach wykluczonych z perspektywy lingwistycznej. "Tekst i Dyskurs" - „Text und Diskurs” III, s. 9-25.

Wósсıк M., 1991: Program wychowania rodzinnego Karola Miarki. W: Żechowsкa B., red.: W kręgu problematyki i metod polskiej pedagogiki. Katowice, s. 64-75.

Wóıсıк M., 1994: Metody wychowania $w$ polskiej rodzinie górnośląskiej $w$ świetle publikacji prasy regionalnej z lat 1869-1914. W: JundzıŁt J., red.: Wychowanie $w$ rodzinie od starożytności po wiek XX. Bydgoszcz, s. 303-310.

Wioletta Wilczek

Patriotic Threads Concerning Family Upbringing in the Upper Silesian Press at the Turn of the $19^{\text {th }}$ and $20^{\text {th }}$ Centuries (on the Erample of Selected Journals)

Summary

The article concerns patriotic threads in the Upper Silesian press concerning the upbringing of children at the turn of the $19^{\text {th }}$ and $20^{\text {th }}$ centuries. The subject of the description are the magazines "Rodzina" and "Katolik" from the years 1890-1918. The analysis included the observed elements of upbringing constituting components of patriotism: cultivation of the mother tongue, love for the 


\section{Wioletta Wilczek}

homeland, memory of history, appreciation of acts of heroism, readiness to sacrifice for the country as well as cultivation of the system of values. The background for the considerations was the historical reality, reflected in the presented content. The basis of the description was the linguistic image of the world and the category of evaluation, which made it possible to indicate the scope of linguistic elements of patriotic upbringing. 